\title{
Sunspot-Climatic Relationships in Fluctuations of Glaciers in the Alps and Atmospheric Precipitation in Korea
}

\author{
By T. Yamamoto \\ Yamaguchi University \\ (Manuscript received 25 May 1961)
}

\begin{abstract}
Relationships between solar activity and climate were studied from the long-term variations of early summer rainfall at Seoul in Korea and from the fluctuations of the Savoie glaciers of the Alps:

It is concluded that strong solar activity, as evidenced by sunspot highs, tends to favor a meridional type of circulation and to intensify thermal convection between middle and high latitudes.

Opposite variation of the high-latitude glaciers and the Alpine glaciers, such as in the neighborhoods of the years 1700 and 1750 , may be explained in terms of heat lost in the middle latiudes and gained in the high latitudes.

The great glacier shrinkage of the last forty years or so, which has run parallel in both the middle and the high latitudes, seems rather an exceptional phenomenon from the standpoint of past history. It is ascribable to an extraordinarily intensified transfer of heat from the lower latitudes and corresponds to a chaotic cellular pattern of general circulation.
\end{abstract}

\section{Introductory remarks}

In a previous study [1] publishd in 1950, I have pointed out that the curve of 11-year running means of early summer rainfall at Seoul, Korea, shows a surprising resemblance to that of sunspot numbers, not only in general features but also in details. Recently I have found in H.W. Ahlmann's "Glacier Variations and Climatic Fluctuations" that the curve showing the variations of the Savoie glaciers in the Alps has been in close agreement with the 11-year running mean of sunspot numbers. Several recent studies of the solar-climatic relationship seem to arrive at a tentative general conclusion that strong solar activity favors a meridional type of circulation pattern and a pattern of blocking, while weak solar activity promotes a zonal pattern of general circulation.

In the present paper an attempt is made to examine the sunspot-climate relationship on the basis of long-term variations of climate in Europe and Asia which have been recorded continuously for more than two centuries.

\section{Long-term variation of rainfall at Seoul as related to sunspot activities}

Some time after the initiation of meteorological observations at Seoul by the Japanese in the year 1908, a continuous record of the amount of precipitation and number of rainy days at Seoul in Korea, from about the middle of the 18th century to the beginning of the 20th century, was discovered and edited by the late Dr. Wada.

The precipitation curve in Fig. 1 exhibits the historical data, extended by the data of meteorological observations since 1908 (adjusted by a suitable multiplier). It is seen that the May-June rainfall at Seoul has increased or decreased in agreement with high or low sunspot numbers.

The sample distribution in Fig. 2 shows that in the Korean June it is more rainy than usual whenever the deviations of air 


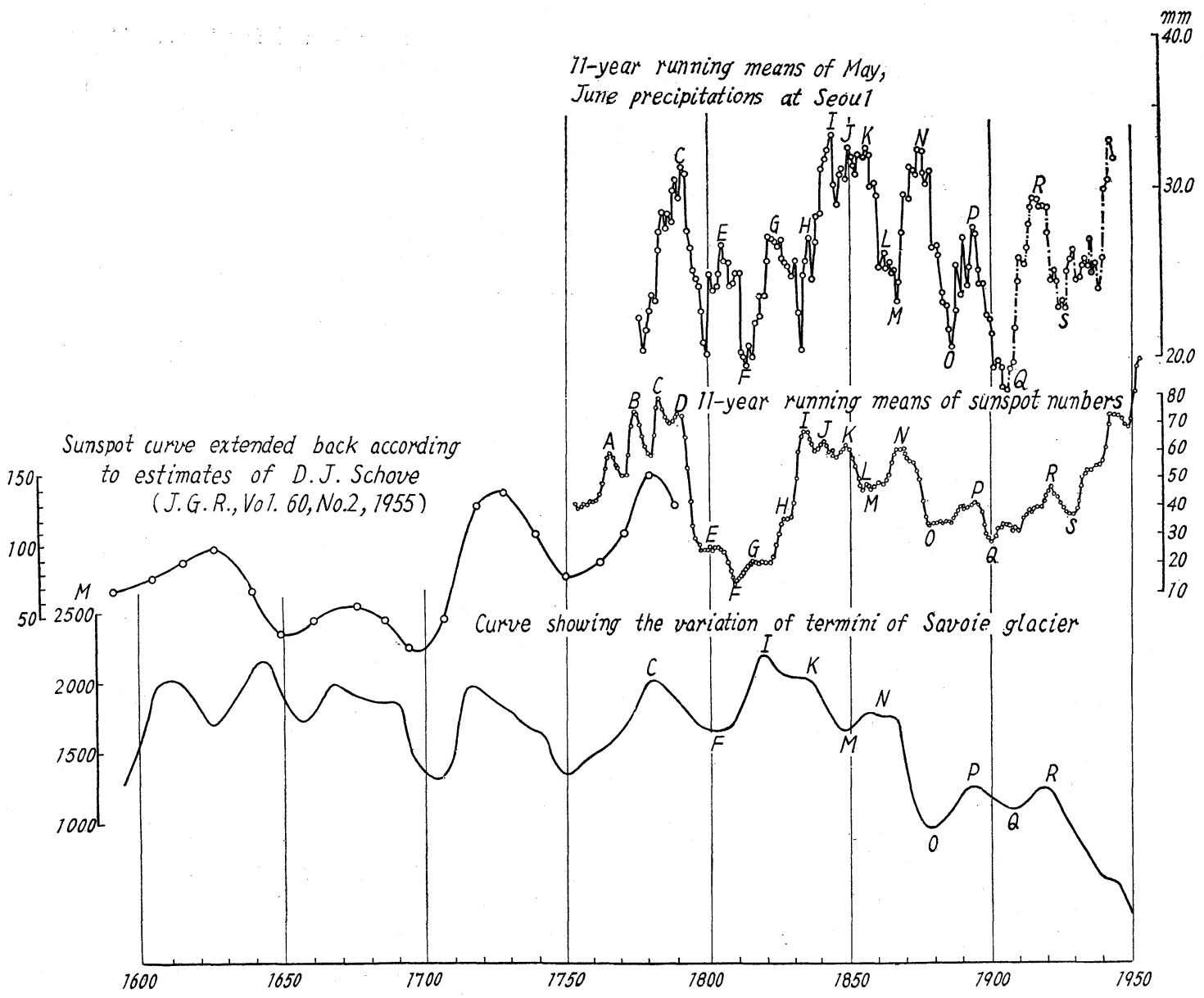

Fig. 1. Curves of eleven-year running means of sunspot numbers and of May-June precipitation at Seoul, together with curves showing variation of the termini of the Savoie glaciers.

temperature are plus on the eastern side of the peninsula and minus on the western side, and vice versa. That is to say, the early summer precipitation in the Korean Peninsula is chiefly controlled by the intensity of the Okhotsk High which blocks the incursion of the warm and humid Pacific High into the Japan Sea.

On the island of Hokkaidō, Japan, the 11year running means of June air temperature at Hakodate $\left(41^{\circ} 49^{\prime} \mathrm{N} 140^{\circ} 45^{\prime} \mathrm{E}\right)$ have been varying in parallel with the sunspot curve (Fig. 3), thus indicating that high sunspot activity corresponds to warm conditions over the northern part of Japan - that is, to a reduced intensity of the Okhotsk High in the early summer.

To test the generally accepted thesis that high sunspot activity favors low-index upper atmospheric circulation, we have applied correlation methods as follows, using the upper air data for Japan.

i) Computed correlation coefficients $R$ for the June $200 \mathrm{mb}$ height gradient, Shionomisaki $\left(33^{\circ} 27^{\prime} \mathrm{N} 135^{\circ} 46^{\prime} \mathrm{E}\right)$ - Wajima $\left(37^{\circ} 23^{\prime} \mathrm{N}\right.$ $\left.136^{\circ} 54^{\prime} \mathrm{E}\right)$ - Akita $\left(39^{\circ} 43^{\prime} \mathrm{N} 140^{\circ} 06^{\prime} \mathrm{E}\right)$, versus the surface air temperature at Hakodate and the upper air temperatures over the northern part of Janan are as follows:

$$
\begin{array}{ll}
R=-0.64 & \begin{array}{l}
\text { for surface air temp. at } \\
\text { Hakodate }(1951-1959, n=9)
\end{array} \\
R=-0.81 & \begin{array}{l}
\text { for } 700 \mathrm{mb} \text { level air temp. } \\
\text { at Akita }\left(39^{\circ} 43^{\prime} \mathrm{N} 140^{\circ} 06^{\prime} \mathrm{E}\right)
\end{array} \\
& (1951-1959, n=9) \\
R=-0.81 & \begin{array}{l}
\text { for } 700 \mathrm{mb} \text { level air temp. } \\
\text { at Sapporo }\left(43^{\circ} 03^{\prime} \mathrm{N} 141^{\circ}\right.
\end{array} \\
& \left.20^{\prime} \mathrm{E}\right) \quad(1951-1959, n=9) \\
\text { for } 700 \mathrm{mb} \text { level air temp. }
\end{array}
$$


at Wakkanai $\left(45^{\circ} 25^{\prime} \mathrm{N} 141^{\circ}\right.$

$\left.41^{\prime} \mathrm{E}\right)$

$(1951-1959, n=9)$

ii) Correlation coefficients for May $200 \mathrm{mb}$ height differences (Shionomisaki, Wajima) versus rainfall in May, computed for several places which are considered to be situated on either side of the mean jet stream position, are as follows:

Left of jet stream entry:

$$
\begin{array}{llr}
R=-0.72 & \text { Seoul } & (1953-1959, n=7) \\
R=-0.56 & \text { Ullung-Do } & \left(37^{\circ} 29^{\prime} \mathrm{N} 130^{\circ}\right. \\
& \left.54^{\prime} \mathrm{E}\right) & (1954-1959, n=6)
\end{array}
$$

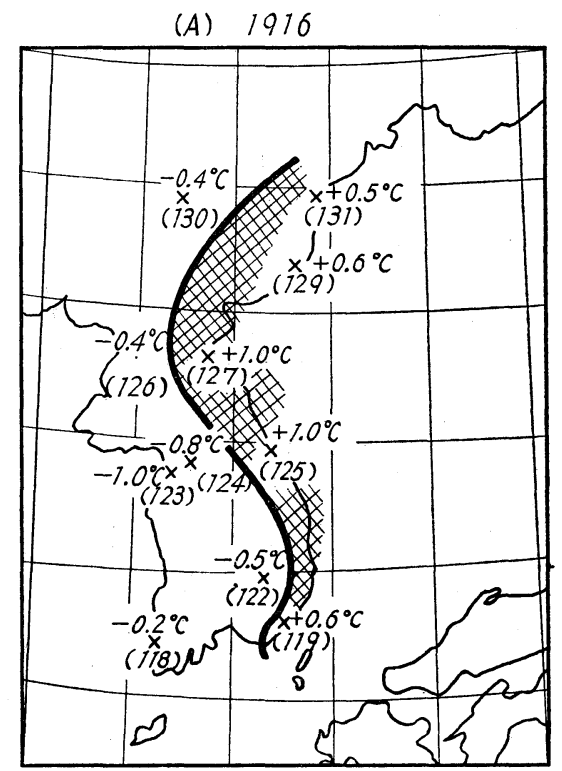

(B) 7932

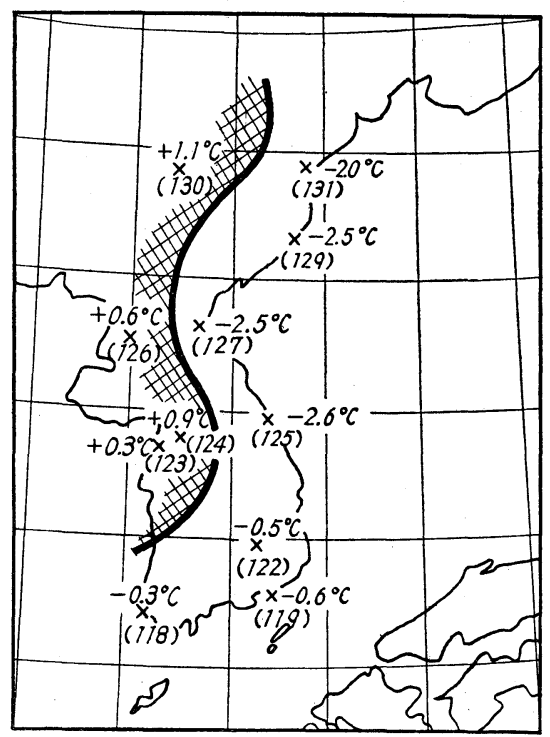

Deviations of amount of precip. in June in Korea

\begin{tabular}{ll|c|c}
\hline \hline & & (A) 1916 & (B) 1932 \\
\hline Pusan & $(119)$ & +345 & -40 \\
Taegu & $(122)$ & +303 & -30 \\
Mokpo & $(116)$ & +309 & -17 \\
Kangnung & $(125)$ & +140 & +9 \\
Inchon & $(123)$ & +195 & -25 \\
Seoul & $(124)$ & +212 & -42 \\
Wonsan & $(127)$ & +12 & -35 \\
Pyongyang & $(126)$ & -26 & -1 \\
Songjin & $(129)$ & -34 & -27 \\
Unggi & $(131)$ & +36 & -55 \\
Chunggangjin & $(130)$ & +17 & -54 \\
\hline
\end{tabular}

Fig. 2. Diviations of June air temperature from long-term mean, for a comparatively rainy year (1916) and for a drier year (1932) in Korea. 

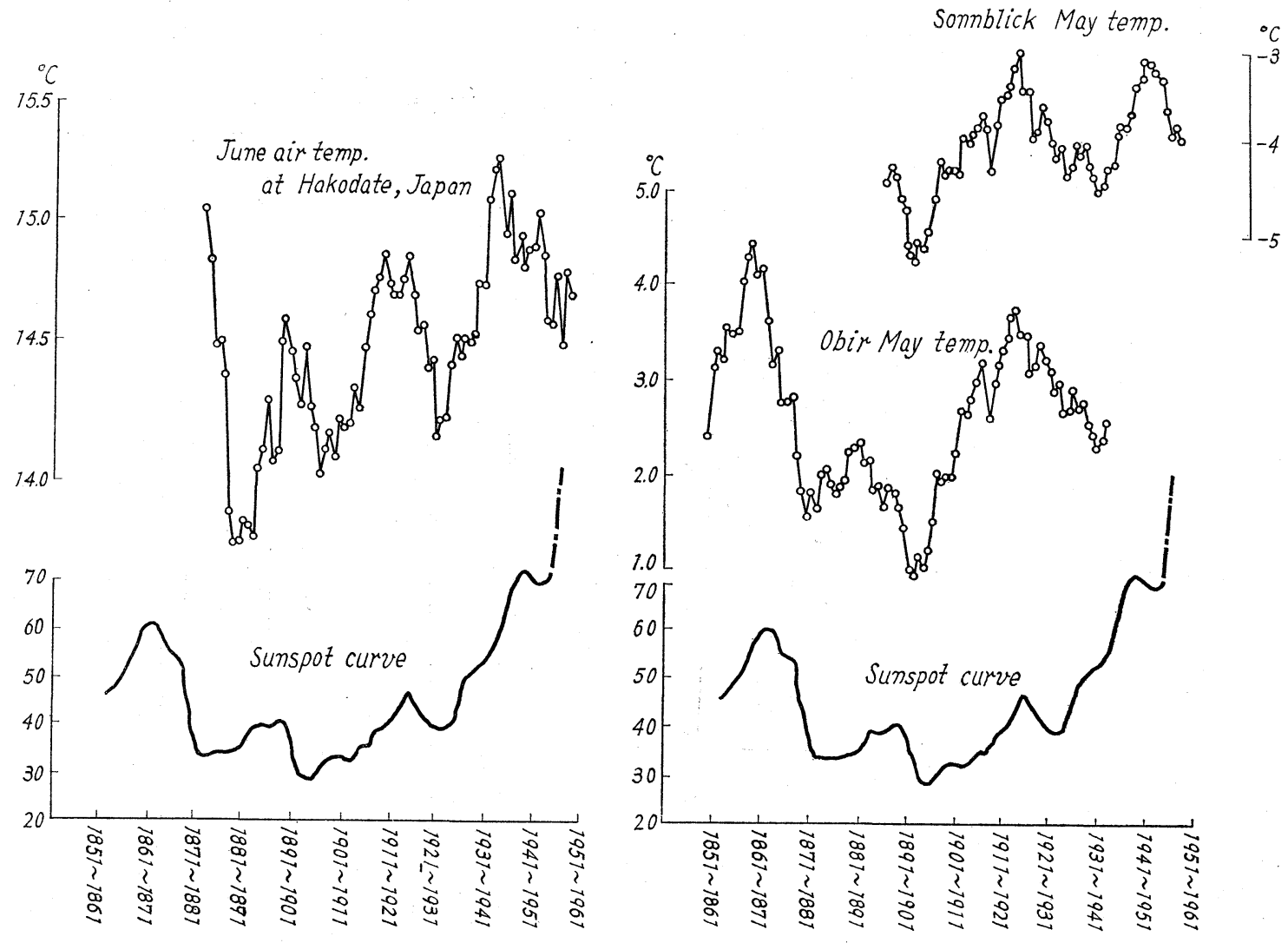

Fig. 3. Eleven-year running means of June air temperature at Hakodate, Japan, and of May air temperature at Sonnblick and Obir, Austria, compared with means of sunspot numbers.

Right of jet stream entry:

$\begin{array}{lll}R=+0.48 & \text { Kagoshima } & \left(31^{\circ} 34^{\prime} \mathrm{N} 130^{\circ}\right. \\ & \left.33^{\prime} \mathrm{E}\right) & \left(1951^{\circ}-1959, n=9\right) \\ R=+0.55 & \text { Yakushima } & \left(30^{\circ} 27^{\prime} \mathrm{N} 130^{\circ}\right. \\ & \left.30^{\prime} \mathrm{E}\right) & \left(1951^{\circ}-1959, n=9\right)\end{array}$

$R=+0.65$ Naze $\left(28^{\circ} 23^{\prime} \mathrm{N} 129^{\circ} 30^{\prime} \mathrm{E}\right)$

$(1951-1959, n=9)$

\section{Left of jet stream exit:}

$R=+0.59 \quad$ Wakkanai $\quad(1951-1959, n=9)$

$R=+0.58$ Haboro $\left(44^{\circ} 22^{\prime} \mathrm{N} 141^{\circ} 42^{\prime} \mathrm{E}\right)$

Right of jet stream exit:

$(1951-1959, n=9)$

$R=-0.40$ Tsukubasan $\left(36^{\circ} 13^{\prime} \mathrm{N} \quad 140^{\circ}\right.$ $\left.06^{\prime} \mathrm{E}\right)$

$$
\begin{aligned}
& R=-0.44 \quad \text { Chōshi }\left(35^{\circ} 43^{\prime} \mathrm{N} 140^{\circ} 51^{\prime} \mathrm{E}\right) \\
& (1951-1959, n=9) \\
& R=-0.38 \text { Tomisaki }\left(34^{\circ} 55^{\prime} \mathrm{N} 139^{\circ} 50^{\prime} \mathrm{E}\right) \\
& \text { (1951-1959, } n=9)
\end{aligned}
$$

The distribution of these correlation coefficients exhibits good agreement with dynamical theory for a direct circulation at the jet entry-point and an indirect circulation at the jet exit-point, in accordance with D.H. Johnson and S.M. Daniels' results on rainfall in the British Isles [2].

We conclude that the sunspot-climate relationships in the Far East may be stated as follows :

High sunspot activity

Decline of mean jet stream over Japan or predominance of meridional type of general circulation in the Far East
Warmer troposphere over northern Japan, associated with enfeeblement of the Okhotsk High in early summer

Frequent incursions of the North Pacific High into the Japan Sea, favoring build-up of intense fronts along the north-south centerline of the Korean Peninsula and bringing more rainfall in May and June at Seoul 

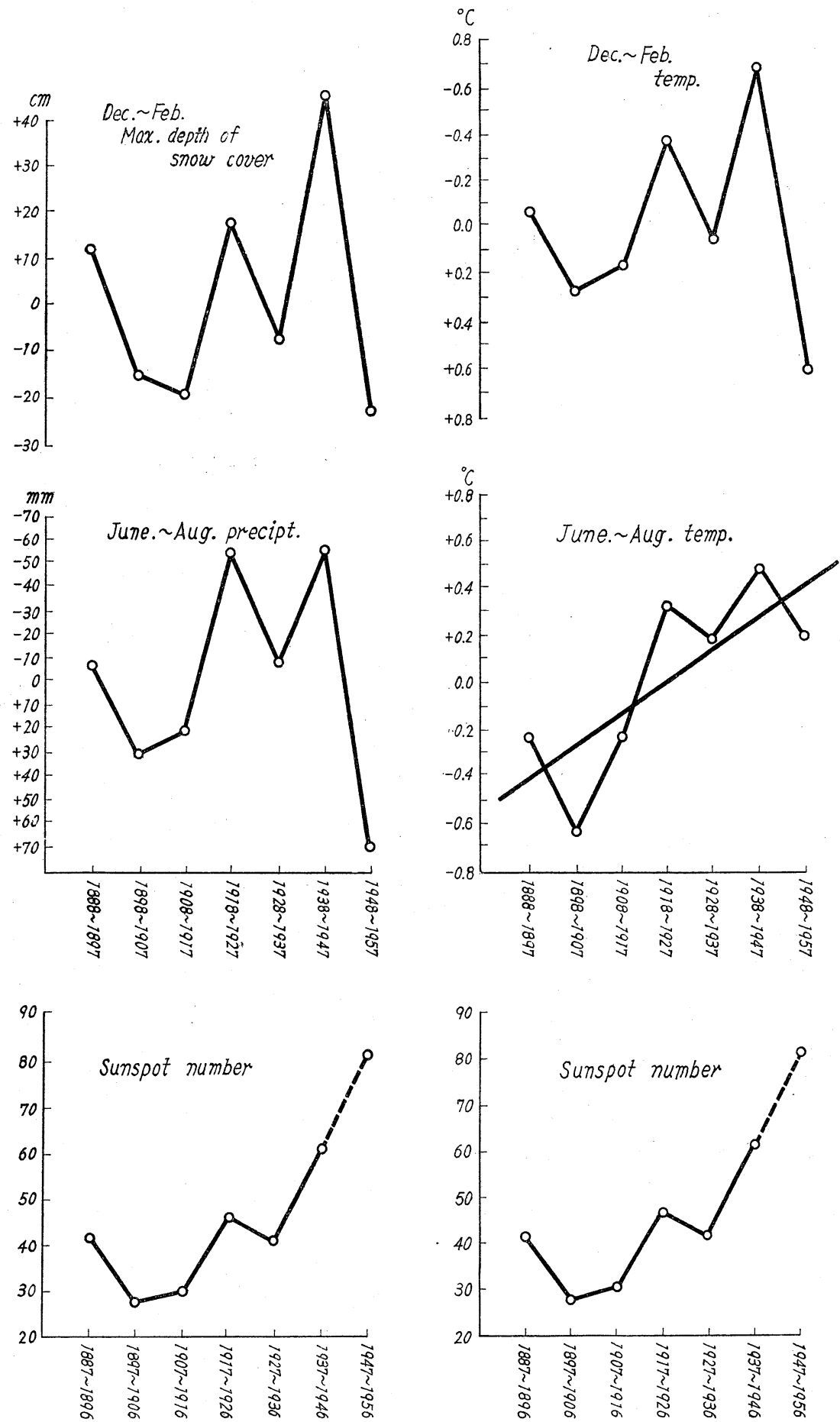

Fig. 4. Comparison of decade means of various climatic factors, Japan.

Dec.-Feb. temp........averaged for 17 places in south-western Japan.

June.-Aug. temp........averaged for 13 places in central and northern Japan. Depth of snow-cover......averaged for 3 coastal places (Kanazawa, Fushiki and Niigata) along the Japan Sea.

June-Aug. precipt.......averaged for 3 points (Matsumoto, Nagano and Fushiki) in central Japan. 
In Fig. 3 it will, however, be seen that from about 1935 - the start of a rapid increase in the general sunspot number toward the present maximum - the solar influence on the June air temperature at Hakodate has apparently reversed its sense ; it now appears that excessive sunspot activity tends to intensify the mean jet stream intensity. There is considerable evidence that a sunspot excess $\overline{(N}=55-60)$ produces a reversal of solar-climatic relationships in the Far East, not only in the case of summer temperatures but also in winter temperatures, summer precipitation and winter snowfall. In the last decade shown in Fig. 4 there is a reversal of the parallelism observed between the decade means of various climatic factors in Japan and those of the sunspot number.

\section{General features of the relationship be- tween glacier fluctuations in the Alps and sunspot activity}

There have been many studies [3] on the relationship between glacier fluctuations and solar activity, and it seems to be accepted as a most valid conclusion that strong solar activity is unfavorable to glaciation, while weak solar activity favors the advance of glaciers. The recent marked trend toward glacier recession, alike in both high and middle latitudes and in both northern and southern hemispheres, appears to correspond to the rapid increase of the general sunspot number.

This accords with recent theory. Nevertheless I should here like to present a new concept of this problem and to discuss the relationship between sunspot activity and glacier conditions from the viewpoint of long-term climatic variations.

In Fig. 1 we reproduce O. Liestol's curve showing the variations of the Savoie glaciers in the Alps. It is astonishing to find close agreement of the Alpine glacier fluctuations with the sunspot curve and with the curve of rainfall in the Far East.

To discuss the relationship of the Alpine glacier fluctuations to the sunspot curve, it is first of all necessary to separate the interval into two parts:

i) the period from 1650 to $1920-1930$, in which strong sunspot activity corresponds to a state of more intense glaciation in the Alps,

ii) the period after $1920-1930$, in which rapid recession of the glaciers corresponds to a steep ascent of the sunspot curve.

The two relationships seem, at first glance, to be contradictory. The relationship for the period (i), which covers by far the greater part of the interval discussed, seems to be generally compatible with the wellknown glaciation theory of G.C. Simpson, according to which an increased solar radiation produces a glacier advance, while minimal solar radiation causes cold dry interglacials. The relationship for the period (ii), on the other hand, agrees with the recent theory that strong solar activity causes retreat of the glaciers, or with Simpson's theory that an excess of solar radiation produces a relatively short stage of warm, wet interglacial conditions.

Whatever truth there is in the above, our problem is to find general relationships between sunspot activity and glaciations such as to account for the facts over the whole interval, through periods (i) and (ii).

\section{Long-term changes of climatic factors in the region of the Alps, as related to mean jet strength}

In Fig. 3, the 11-year running means of May air temperature at the Austrian mountain observatories of Obir $\left(46^{\circ} 30^{\prime} \mathrm{N} 14^{\circ}\right.$ $29^{\prime} \mathrm{E}$, altitude $2044 \mathrm{~m}$ ) and Sonnblick $\left(47^{\circ} 03^{\prime} \mathrm{N}\right.$ $\left.12^{\circ} 57^{\prime} \mathrm{E}, 3106 \mathrm{~m}\right)$ are compared with the sunspot curve over the full interval for which data are available.

It is seen that the temperature curves change in parallel with the sunspot curves except in the final part, since about the year 1940 - the period during which the general sunspot number has been in excess.

In the same way as for Hakodate, we have investigated the correlation of air temperature over the Alps with the mean jet strength. The $300 \mathrm{mb}$ height gradient, Cairo $\left(30^{\circ} 08^{\prime} \mathrm{N}\right.$ $\left.31^{\circ} 34^{\prime} \mathrm{E}\right)-\mathrm{Nicosia}\left(35^{\circ} 09^{\prime} \mathrm{N} 33^{\circ} 17^{\prime} \mathrm{E}\right)$-Ankara $\left(39^{\circ} 57^{\prime} \mathrm{N} 32^{\circ} 53^{\prime} \mathrm{E}\right)$, was selected as our zonal index of the mean jet-stream strength, on the basis of J.R. Bannon's figures for mean upper-air flow [4]. The air temperatures in the region of the Alps show significant 
negative correlations with the upper-air zonal index, the coefficients being:

$$
\begin{array}{ll}
R=-0.80 & \text { for Sonnblick (1952-1959, } n=8) \\
R=-0.79 & \text { for Villacher-Alpe }\left(46^{\circ} 36^{\prime} \mathrm{N}\right. \\
& \left.13^{\circ} 40^{\prime} \mathrm{E}, 2135 \mathrm{~m}\right)(1952-1958, n=7) \\
R=-0.69 & \text { for Santis }\left(47^{\circ} 14^{\prime} \mathrm{N} 9^{\circ} 21^{\prime} \mathrm{E},\right. \\
& 2496 \mathrm{~m})
\end{array}
$$

The correlation coefficients for air temperature at $700 \mathrm{mb}$ and $200 \mathrm{mb}$ heights versus the upper-air zonal index over the Near East are distributed as shown in Fig. 5 . It is of great interest that in the middle-latitude European zone, centering on the Alps, the distribution of the correlation coefficients for $200 \mathrm{mb}$ level temperatures is in marked contrast to that of the $700 \mathrm{mb}$ level temperatures.

The relationships of the upper-air zonal index in the Near East with air temperature, lapse-rate and humidity in the upper air at

\begin{tabular}{|c|c|c|c|c|c|c|}
\hline Year & $\begin{array}{c}\text { (a) } \\
\text { Upper-air } \\
\begin{array}{c}\text { zonal ináex } \\
\text { (m/deg.) }\end{array}\end{array}$ & $\begin{array}{c}(\mathrm{b}) \\
700 \mathrm{mb} \\
\text { temp. }\left({ }^{\circ} \mathrm{C}\right)\end{array}$ & $\begin{array}{c}\text { (c) } \\
200 \mathrm{mb} \\
\text { temp. }\left({ }^{\circ} \mathrm{C}\right)\end{array}$ & $\begin{array}{c}(\mathrm{d}) \\
\text { Lapse-rate between } \\
700 \mathrm{mb} \text { and } 200 \mathrm{mb} \\
\text { heights }\left(-{ }^{\circ} \mathrm{C} / 100 \mathrm{~m}\right)\end{array}$ & $\begin{array}{c}\text { (e) } \\
850 \text { mb height, } \\
\text { humidity number } \\
\text { (temp.-dew point) }\end{array}$ & $\begin{array}{l}\text { (f) } \\
500 \mathrm{mb} \text { height, } \\
\text { humidity number }\end{array}$ \\
\hline 1952 & -1.2 & $-1 .{ }^{\prime} 0$ & -1.7 & +0.10 & -0.1 & +0.4 \\
\hline 1953 & +6.5 & +0.4 & -1.4 & +0.21 & +1.2 & +1.8 \\
\hline 1954 & +3.4 & -0.6 & +0.9 & -0.15 & -0.8 & -0.9 \\
\hline 1955 & -2.9 & -1.9 & +0.8 & -0.28 & +1.0 & +0.5 \\
\hline 1956 & +6.2 & +0.6 & +0.8 & -0.04 & +0.2 & +0.6 \\
\hline 1957 & +11.1 & -2.0 & +4.1 & -0.68 & -1.6 & -1.0 \\
\hline 1958 & -15.3 & +3.8 & -3.8 & +0.80 & +1.2 & -0.9 \\
\hline 1959 & -8.1 & +0.7 & +0.2 & +0.05 & -0.9 & -0.5 \\
\hline Mean & $\begin{array}{c}29.0 \\
(\mathrm{~m} / \mathrm{deg} .)\end{array}$ & $\begin{array}{c}-3.8\left({ }^{\circ} \mathrm{C}\right) \\
\mathrm{R}_{a b}=-0.73\end{array}$ & $\begin{array}{l}-56.4\left({ }^{\circ} \mathrm{C}\right) \\
\mathrm{R}_{a c}=+0.71\end{array}$ & $\begin{array}{c}0.60\left(-{ }^{\circ} \mathrm{C} / 100 \mathrm{~m}\right) \\
\mathrm{R}_{a d}=-0.73\end{array}$ & $\begin{array}{c}5.4\left({ }^{\circ} \mathrm{C}\right) \\
\mathrm{R}_{a e}=-0.67\end{array}$ & $\begin{array}{c}9.4\left({ }^{\circ} \mathrm{C}\right) \\
\mathrm{R}_{a f}=+0.29\end{array}$ \\
\hline
\end{tabular}
München $\left(48^{\circ} 08^{\prime} \mathrm{N} 11^{\circ} 42^{\prime} \mathrm{E}\right)$ are tabulated as follows :

Table 1. Contemporary correlation of $300 \mathrm{mb}$ height gradient (Cairo-Nicosia-Ankara) with upper-air data at München in May.

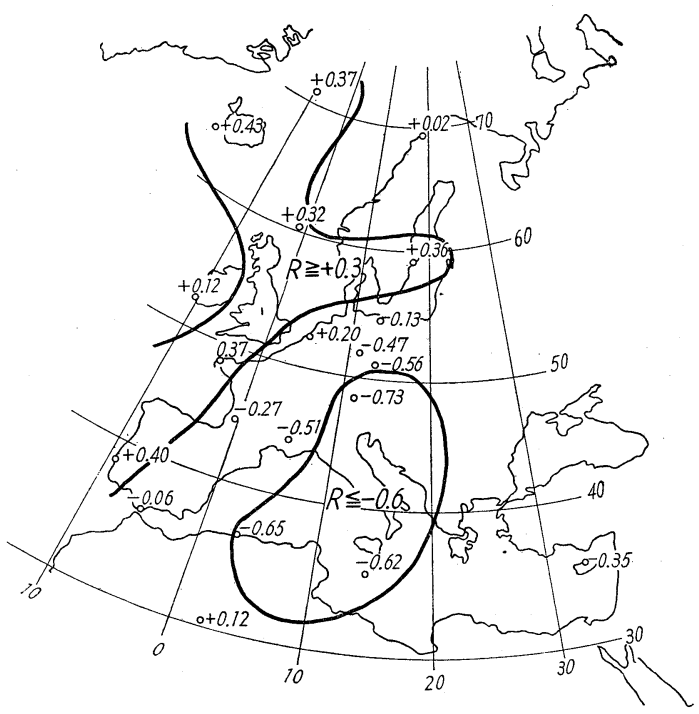

(a)

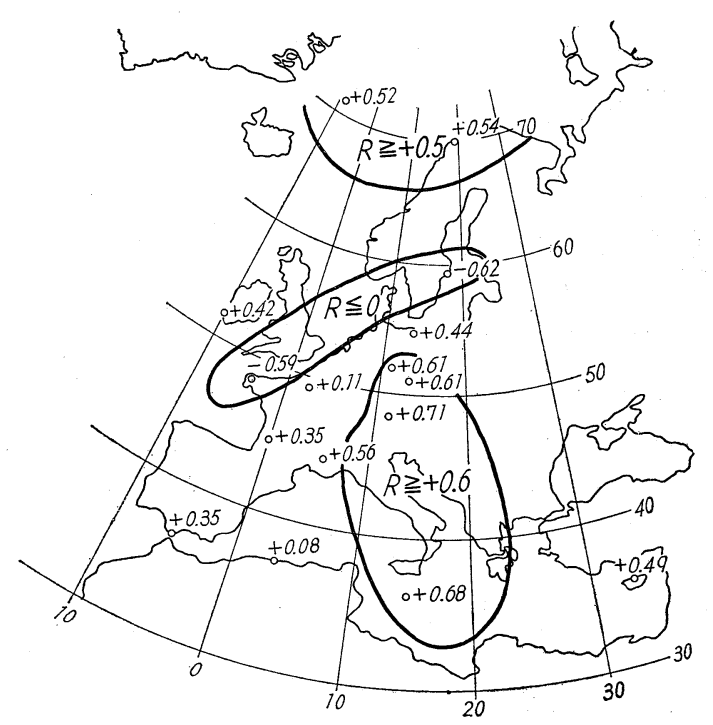

(b)

Fig. 5. Distributions of correlation coefficients, upper-air temperature in May versus zonal index over the Near East. (a) Air temperature at $700 \mathrm{mb}$ height. (b) Air temperature at $200 \mathrm{mb}$ height. 
The conclusions from Table 1 are that warmer and drier conditions in the lower part of the troposphere in the region of the Alps are associated with the declined state of the mean jet-stream intensity in the Near East, and that the long-term relationship of May air temperature at Obir with the sunspot curve, as in Fig. 3, is to be interpreted as meaning that strong solar activity favors the decline of mean jet intensity in Europe also. Thus the case is just the same as that of the long-term variation of Korean rainfall, and just the same as that of air temperature at Hakodate in Japan.

\section{Discussion of the relationship between sunspot activity and the long-term glacier fluctuations}

The tendency of the May climatic factors and the upper-air zonal index to be related as in Table 1 persists more or less throughout all the seasons. For instance, the correlation coefficients for lapse-rate (difference of $700 \mathrm{mb}$ level and $200 \mathrm{mb}$ level temperatures) at München versus the zonal indices for $300 \mathrm{mb}$ height in Europe are computed for every other month as follows:

Table 2. Correlation coefficients of $700 \mathrm{mb}-200 \mathrm{mb}$ temperature-differences at München versus upper-air zonal index, $300 \mathrm{mb}$ level.

\begin{tabular}{|c|c|c|c|}
\hline Month & $\begin{array}{l}\text { Correlation } \\
\text { coefficient }\end{array}$ & Zonal index & Period \\
\hline Jan. & $\mathrm{R}=-0.51$ & Cairo-Ankara & $1951-1959, \quad n=9$ \\
\hline Mar. & $R=-0.81$ & $\begin{array}{l}\text { Algiers }\left(36^{\circ} 43^{\prime} \mathrm{N} 3^{\circ} 14^{\prime} \mathrm{E}\right) \text {-Nîmes } \\
\left(43^{\circ} 52^{\prime} \mathrm{N} 4^{\circ} 24^{\prime} \mathrm{E}\right)\end{array}$ & $1952-1959, \quad n=8$ \\
\hline May. & $\mathrm{R}=-0.74$ & Cairo-Ankara & $1952-1959, n=8$ \\
\hline July & $\mathrm{R}=-0.73$ & Qrendi $\left(35^{\circ} 50^{\prime} \mathrm{N} 14^{\circ} 27^{\prime} \mathrm{E}\right)$-München & $1952-1959, n=8$ \\
\hline Sept $†$ & $\mathrm{R}=-0.71$ & Algiers-Nîmes & $1953-1959, \quad n=7$ \\
\hline Nov. & $\mathrm{R}=-0.76$ & Algiers-Nîmes & $\begin{array}{c}1951-1959, \quad n=7 \\
(1952,1957 \text { missed })\end{array}$ \\
\hline
\end{tabular}

$\dagger$ Only for the month of Sept., the temperature at Milano $\left(45^{\circ} 28^{\prime} \mathrm{N} 9^{\circ} 17^{\prime} \mathrm{E}\right)$ is used.

Fig. 6 shows that the 11-year running mean curves of annual mean temperatures at Sonnblick and of the annual amounts of precipitation at Obir, extended to earlier years by the figures for precipitation at Lyon $\left(45^{\circ} 43^{\prime} \mathrm{N} 4^{\circ} 55^{\prime} \mathrm{E}, 202 \mathrm{~m}\right)$, bear a close resemblance to the sunspot curve.

The relation between Alpine glacier activity and the sunspot curve seems to be quite paradoxical, for the conclusion is that the glacier grows under the warmer and drier conditions (at least, in the lower part of the troposphere in the vicinity of the Alps) associated with weak jet streams. This seems to have been the case throughout the long time-interval of Fig. 1 except during the recent recession period of 40 years or so.

I should like to present my opinion that the explanation of this paradoxical relationship may be found only in radiation processes. The most important factor modifying the long-term variation of the Alpine glaciers
(Fig. 1) must have been a radiation-loss during period (i) of Section 3.

As we see in Table 2, the lapse-rate over the Alps shows a close negative correlation with the upper-air zonal index in Europe throughout the year; or otherwise stated, the temperature-differences between the lower and higher parts of the troposphere in the middle latitudes of Europe become larger in periods of high sunspot activity.

The so-called "temperate glaciers" in middle or low latitude (according to the thermal classification of glaciers as employed by Lagally and by Ahlmann [5], that is, glaciers in which the temperature at any depth is at the melting point corresponding to the pressure at that depth, except in a surface layer which during winter loses heat to the atmosphere and so temporarily has a negative temperature) may have a content of water throughout the entire thickness of the glacier. It seems to me very probable that 


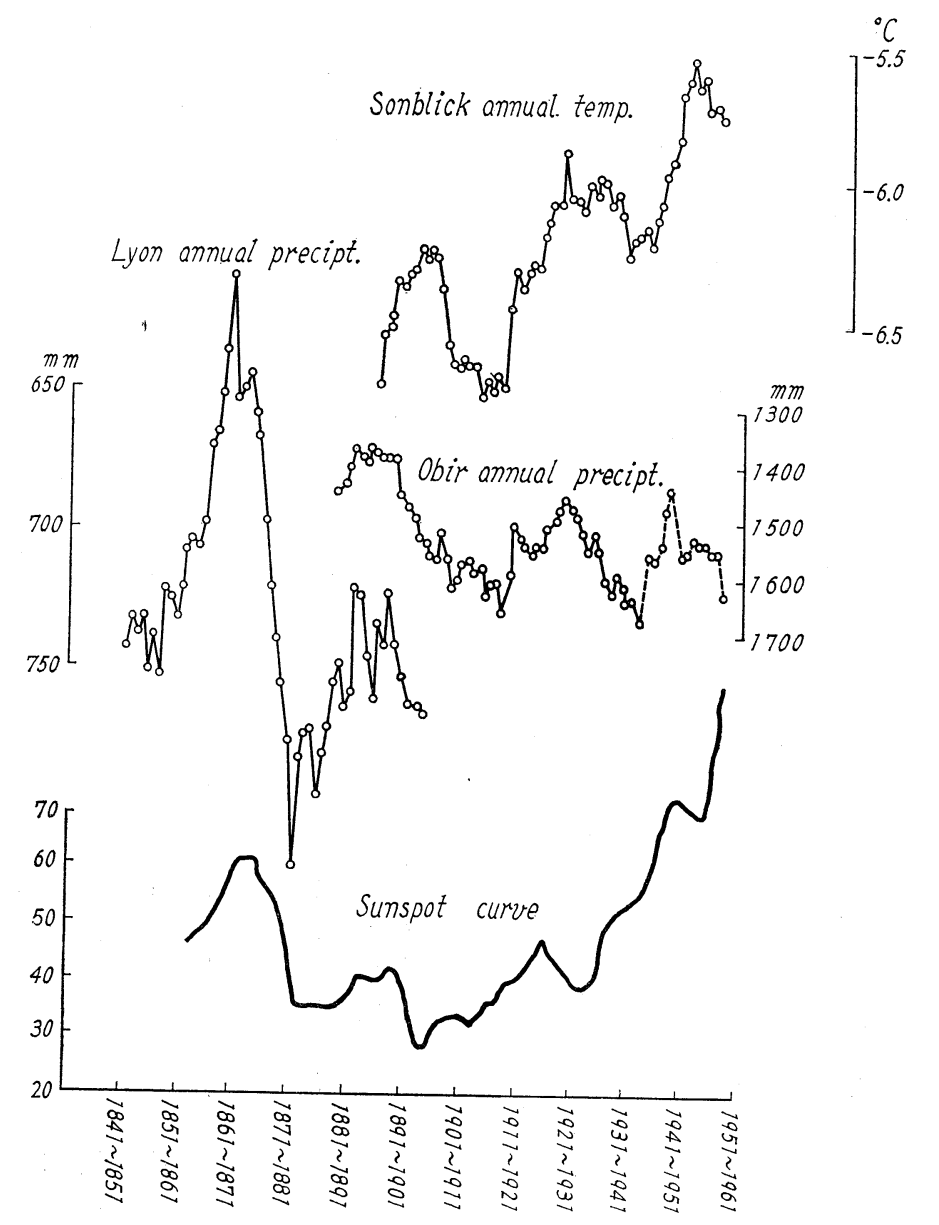

Fig. 6. Eleven-year running means of annual mean air temperature at Sonnblick and of annual precipitation at Obir and Lyon, compared with means of sunspot numbers.

the radiation loss will cause a refreezing of this water-content, so that ablation is prevented and the expansion of the glacier promoted.

Though I have stated above that warmer and drier conditions favor high activity of the Alpine glaciers, this is true only in the lower part of the troposphere, below $2000 \mathrm{~m}$. It must be noted that at the altitute of Sonnblick, for instance, the monthly means of air temperature are almost always below $0^{\circ} \mathrm{C}$, except in July, August, and September. The correlation of humidity at the $500 \mathrm{mb}$ level with mean jet strength in Table 2 exhibits rather the opposite tendency as compared with the $850 \mathrm{mb}$ level. The decade means of annual precipitation at Sonnblick
Table 3. Comparison of the decade means of annual precipitation at Sonnblick and at Lyon.

\begin{tabular}{c|c|c}
\hline Decade & Sonnblick & Lyon \\
\hline $1891-1900$ & $1787(+215)$ & $739(-52)$ \\
$1901-1910$ & $1674(+102)$ & $757(-34)$ \\
$1911-1920$ & $1539(-33)$ & $774(-17)$ \\
$1921-1930$ & $1367(-205)$ & $828(+37)$ \\
$1931-1940$ & $1494(-78)$ & $858(+67)$ \\
\hline Means & $1572 \mathrm{~mm}$ & $791 \mathrm{~mm}$ \\
\hline
\end{tabular}


have been decreasing, in contrast to the increase of precipitation at Lyon, as Table 3 shows.

If it be admitted that in the vicinity of the Alps the humidity and precipitation in the higher part of the troposphere change oppositely to those in the lower parts, then my new concept of the relationships may be pictured as follows, in confrontation with Simpson's theory.

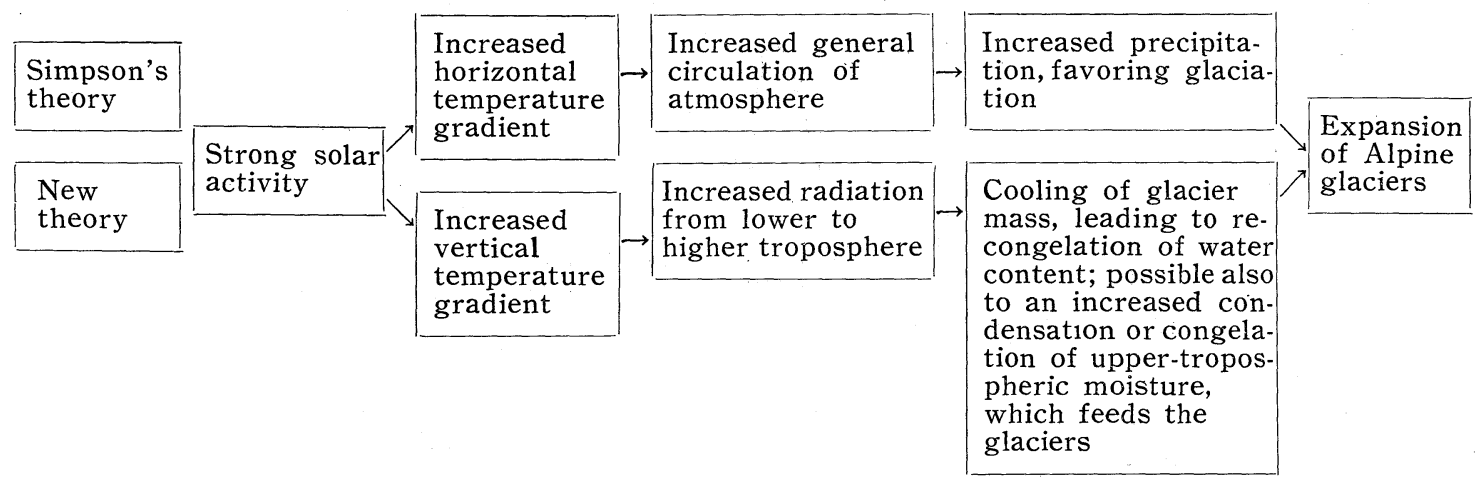

The decade means of annual precipitation at Stykkisholm in Iceland, Valentia in Ireland and Lyon in France are compared in Fig. 7, where we have taken the decade the same as for Japan in Fig. 4.

Our result here is very important. Precisely inverted seesaws are observed in the decade variations of precipitation in the higher and in the middle latitudes, indicating that strong sunspot activity tends to displace the prevailing storm-tracks polewards and vice versa, both in Europe (Fig. 7) and in Japan (Fig. 4). In the last decade, however, the solar-climatic relationships have been upset.

The poleward migrations of the stormtracks might intensify thermal convection in the higher latitudes, and thus reduce glaciation, for according to Ahlmann and Thorarinsson [6] convection plays a much more important part than radiation in the ablation processes for the high-latitude glaciers, such as those of Iceland.

In Fig. 8, reproduced from Ahlmann, the high-latitude glaciers exhibit maxima in the neighborhoods of 1700,1750 , and 1850 , corresponding to the minima of the Alpine glaciers. This fact may now be explained by the above relationship, that is to say, by equatorward migrations of the storm-tracks at low sunspot activity. Such migrations might reduce thermal convection in the higher-latitude zone, while the weak solar activity favored the recession of the Alpine

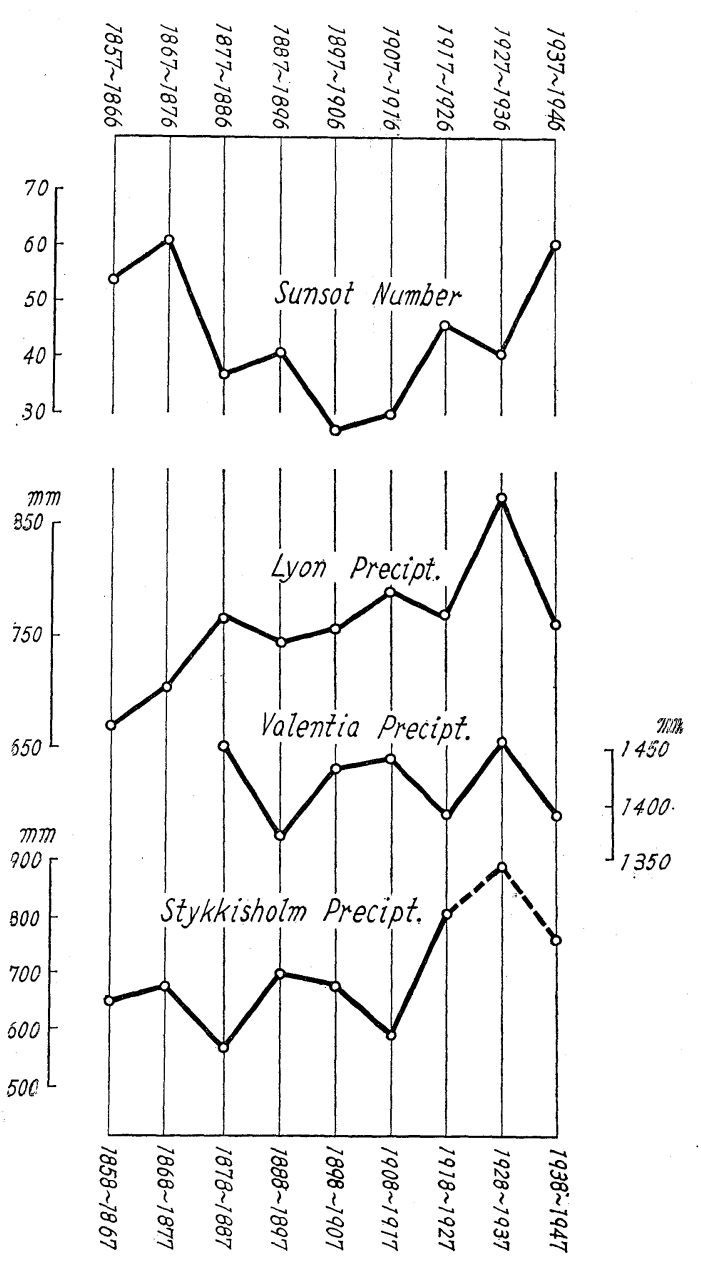

Fig. 7. Decade means of annual precipitation at Stykkisholm, Iceland, at Valentia, Ireland, and at Lyon, France, compared with decade means of sunspot numbers. 


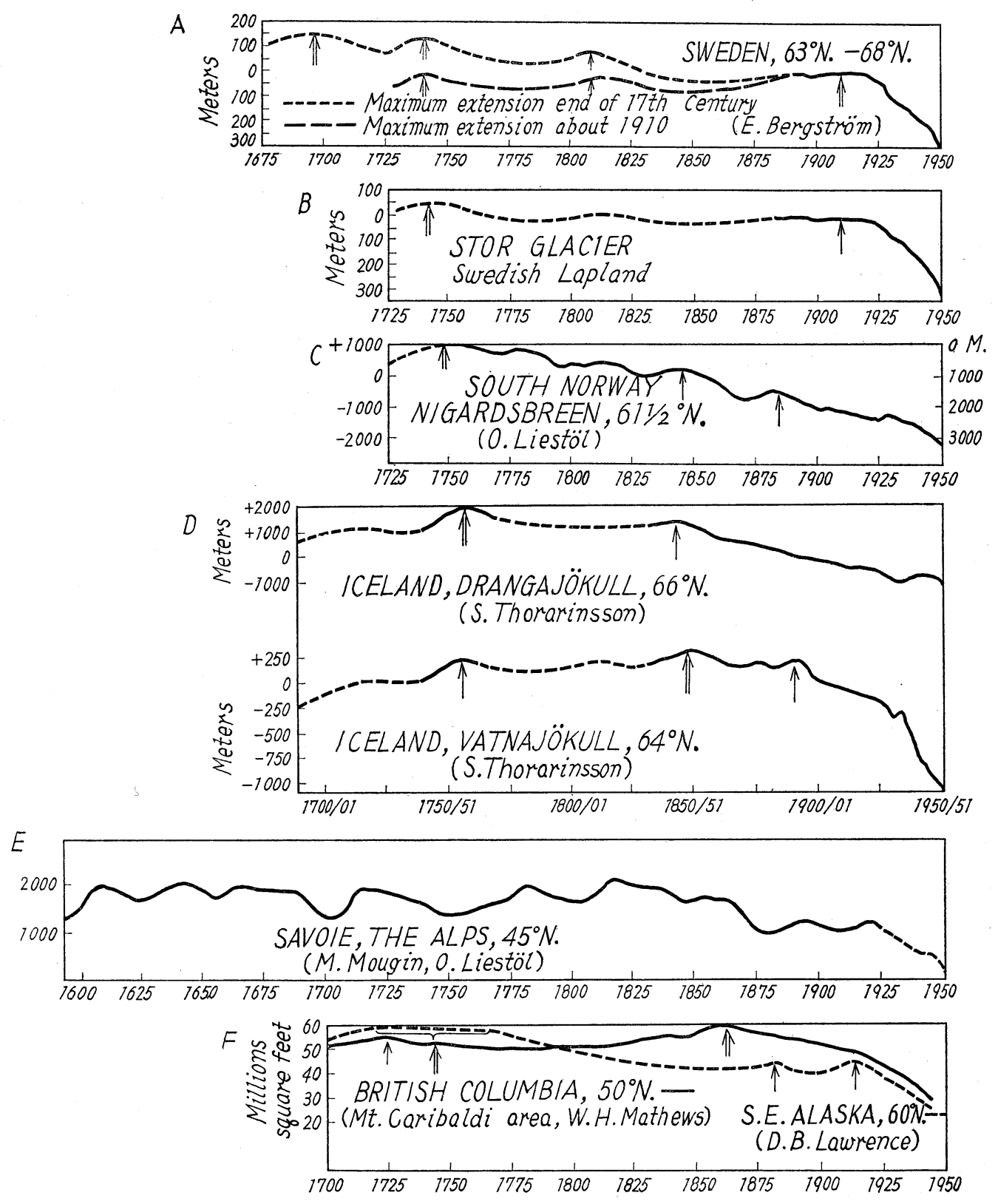

Fig. 8. Curves showing the variations of glacier termini.

glaciers.

After about 1920, precipitation suddenly increased in every part of Europe (Fig. 7), inverting the previous sunspot-climatic relationship. The same thing is observed from about 1945 in Japan (Fig. 4). It seems to me that a chaotic cellular pattern of general circulation developed in the European-Atlan- tic sector since about 1920 , a pattern which might have been partly the effect of the excessively large number of sunspots, and partly, I suppose, the effect of an increase of atmospheric condensation nuclei over Europe.

It is possible that since 1920 , under conditions of greater transport of heat from the 
lower latitudes, parallel stages of glacier recession may have occurred in the high latitudes and in the Alps.

\section{Acknowledgement}

I should like to express my sincere thanks to Dr. H. Landsberg, Director of the Office of Climatology, U.S. Weather Bureau, to Prof. Dr. F. Steinhauser, Director of the Zentralanstalt für Meteorologie und Geodynamik, to Dr. P. Thrane, Director of the Norske Meteorologiske Institutt, and to Mr. Kong Sam Pak, Central Meteorological Observatory, Korea, who were kind enough to send me climatic data indispensable for the present research.

I am extremely grateful to Mr. E.R. Hope, Defence Research Board in Canada, who gave me many kind considerations and suggestions for this paper.

\section{References}

1. Yamamoto T., 1951: On the secular change of the climate in Japan (II). Geophysical Magazine, 22, No. 1.

, 1956: On the climatic change in Japan and its surroundings. Proceedings of the Eighth Pacific Science Congress.

2. Johnson D.H. and S.M. Daniels, 1954 : Rainfall in relation to the jet stream. Q.J. R.M.S., 80, No. 344 .

3. Willett, H.C., 1951: Extrapolation of sunspotclimate relationships. Jour. Met., 8, No. 1.

, 1951: Solar influences on the weather. Transactions of New York Academy of Sciences, 13, No. 7.

4. Bannon, J.K., 1953: Mean upper-air flow. Toronto Meteorological Conference.

5. Flint, R.F., 1957: Glacial and Pleistocene Geology, p. 16 .

6. Ahlmann, H.W., 1953: Glacier variations and climatic fluctuations. Bowman Memorial Lectures, Series 3, Am. Geog. Soc., 8-58.

\section{アルプスの水河および朝鮮の降水の変動と太陽黒点との関係}

$\begin{array}{ccc}\text { 山 } & \text { 本 } & \text { 夫 } \\ \text { (山 口 } & \text { 大 } & \text { 学) }\end{array}$

太陽黒点活動度と気候変動との関係を, 朝鮮 Seoul の初夏の降水量と, アルプス Savoie 水河の長期変動を中心 そしらべた。(Fig. 1 参照)

5 月の Seoul の降水量と, 5 月の[潮岬・輪島] の $200 \mathrm{mb}$ 高度差との相関係数は $R=-0.72$ (1953 年 $\sim 1959$ 年 $n=7$ ）であるから, Fig. 1 飞見られる Seoul の初夏の雨量と太陽黒点数の長期変動の関係は, 太陽活動度の 大（又は小）が各々，大循環飞招ける子午線方向（又は緯度方向）の循環の卓越に対応するという一般的関係を与 えること市る。

近東に和ける 5 月の $300 \mathrm{mb}$ 高度の傾度 $\left[\right.$ Cairo $\left.\left(\begin{array}{l}30^{\circ} 08^{\prime} \mathrm{N} \\ 31^{\circ} 34^{\prime} \mathrm{E}\end{array}\right)-\mathrm{Nicosia}\left(\begin{array}{l}35^{\circ} 09^{\prime} \mathrm{N} \\ 33^{\circ} 17^{\prime} \mathrm{E}\end{array}\right)-\operatorname{Ankara}\left(\begin{array}{l}39^{\circ} 59^{\prime} \mathrm{N} \\ 32^{\circ} 53^{\prime} \mathrm{E}\end{array}\right)\right]$ とア ルプス付近の上層気温の関係は, Fig. 5 飞示市よう飞 $700 \mathrm{mb}$ 高度の気温については負, $200 \mathrm{mb}$ 高度の気温につい ては正である。この関係と Fig. 3 飞見られるような山岳観測所 Obir $\left(\begin{array}{l}46^{\circ} 30^{\prime} \mathrm{N} \\ 14^{\circ} 29^{\prime} \mathrm{E}\end{array} 2044 \mathrm{~m}\right)$ や Sonnblick $\left(\begin{array}{l}47^{\circ} 03^{\prime} \mathrm{N} \\ 12^{\circ} 57^{\prime} \mathrm{E}\end{array}\right.$ $3106 \mathrm{~m})$ の 月気温と太陽黒点数の長期変動の関係から, 太陽現象と気候飞ついて, 上述と同じ結論が得られる。

Fig. 1 飞見られる太陽黒点数とアルプス水河の長期変動の関係は, 最近の 30 年〜 40 年を除く, 過去 300 年の長 期飞わたり，太陽活動の大(小)が各々，氷河の進出（縮退）飞対応するという Simpson 説の関倸を示す。このよう なアルプス水河の消長は Fig. 8 飞和いて 1700 年，1750 年，1850 年付近飞見られるようと，高緯度水河とは逆の 傾向の変動をしている。このような種々の事実から筢者は太陽活動度と中緯度水河の活動の関係について Simpson 説と対比しつつ次のような新仮説を提出したい。 


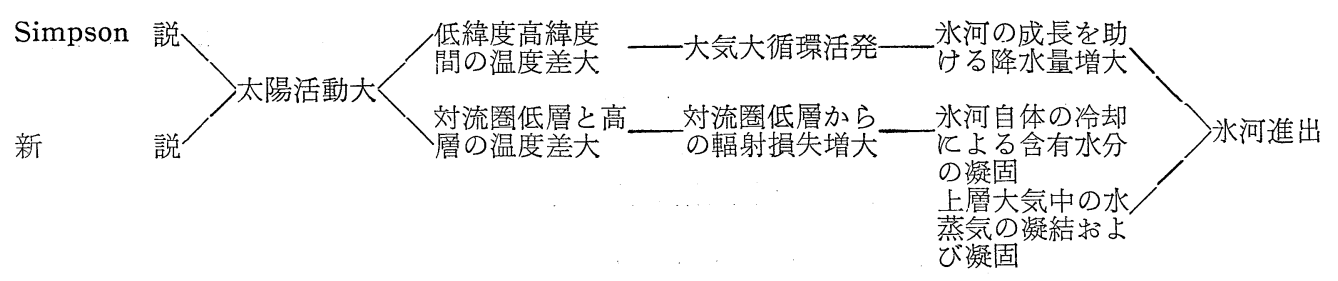

以上述べたような一般的関係はヨーロッパや極東の種々の気候要素について, 最近の太陽黒点数の異常な增大とと もと逆転している傾向が見られる。(Fig. 3, Fig. 4, Fig. 7 参照)

最近飞郝ける中緯度高緯度を通じての氷河の著しい縮退傾向もこれらと関連する現象と考えられる。 